\title{
First records of two freshwater lichens, Hydropunctaria scabra and Verrucaria alpicola, from Bulgaria
}

\section{Veselin V. Shivarov ${ }^{1 *}$, Holger Thüs ${ }^{2} \&$ Cvetomir M. Denchev ${ }^{1}$}

\author{
${ }^{1}$ Institute of Biodiversity and Ecosystem Research, Bulgarian Academy of Sciences, 2 Gagarin St., 1113 \\ Sofia, Bulgaria \\ ${ }^{2}$ Life Sciences Department, The Natural History Museum, Cromwell Road, London SW7 5BD, United \\ Kingdom
}

Received 31 January 2017 / Accepted 13 February 2017 / Published 22 February 2017

Shivarov, V.V., Thüs, H. \& Denchev, C.M. 2017. First records of two freshwater lichens, Hydropunctaria scabra and Verrucaria alpicola, from Bulgaria. - Mycobiota 7: 1-5. doi: 10.12664/mycobiota.2017.07.01

\begin{abstract}
Two lichen-forming fungi, Hydropunctaria scabra and Verrucaria alpicola (Verrucariaceae, Ascomycota), are reported for the first time from Bulgaria. Descriptions and ecological observations based on the Bulgarian populations are provided. For Verrucaria alpicola the ability to survive a continuous submersion over a period of at least four years is confirmed.
\end{abstract}

Key words: Bulgaria, freshwater habitats, lichen-forming fungi, Verrucariaceae

\section{Introduction}

Freshwater lichens constitute an ecological group of fungi with a more or less distinctive affinity to freshwater habitats. Depending on their tolerance of submersion, three groups of freshwater lichens can be distinguished: aquatic, sub-aquatic (amphibious), and riparian, the last one being a group of species with a large ecological amplitude which extends up to a certain level into the (semi-) aquatic environment (Thüs \& Schultz 2008). Less than ten species are confirmed to be able to survive several years of continuous inundation, whereas the total number of lichens with a distinct affinity to freshwater habitats comprise about 250 species, most of which are amphibious, tolerating only limited periods of inundation (Thüs et al. 2014).

Forty freshwater lichens are known to occur in Bulgaria. Twenty-three of them are members of the Verrucariaceae. Some typical aquatic lichens (e.g. Hydropunctaria rheitrophila) were recently recorded from Bulgaria (Shivarov 2013), but higher numbers of

\footnotetext{
*Corresponding author: e-mail: v.shivarov@abv.bg
} 
freshwater lichens can be expected due to the diversity of suitable habitats and the limited degree of exploration so far (Shivarov 2015). Two additional species were found during field examinations in the framework of a project for studying freshwater lichens in the watersheds of Demyanitsa River (Pirin Mts) and Malyovitsa River (Rila Mts) and we provide detailed descriptions.

\section{Material and methods}

The studied specimens are deposited at the Mycological Collection of the Institute of Biodiversity and Ecosystem Research, Sofia (SOMF). The presented measurements of ascospores and their shape terminology follow Smith et al. (2009). The measurements were made in $10 \% \mathrm{KOH}$ for the ascospores and distillated water was used for the rest of the structures. The observations and measurements were made under Windaus Labortechnik D-38678 dissecting microscope equipped with a Canon PowerShot A630 digital camera and Boeco BM-180/T/SP microscope with mounted digital camera HP Photosmart M517. The provided photograph from the field was made by the first author with Canon PowerShot SX 710 HS. All photographs were additionally edited and adapted with specialized software Adobe Photoshop CS5.1 and Carnoy 2.0.

\section{Morphological descriptions of Bulgarian specimens}

Hydropunctaria scabra (Vẽzda) C. Keller, Gueidan \& Thüs, Taxon 58: 194, 2009.

Figs 1, 2

Thallus $80-140 \mu \mathrm{m}$ thick, epilithic, subgelatinous, dark olive green (in the habitat with black to dark bluish green colour); thalline surface with numerous black punctae, sometimes cracked, smooth or roughened by the tips of black columns. Prothallus absent. Cortex paraplectenchymatous, green to yellowish green, with algal cells arranged in vertical columns; upper cortex with dark green pigment. Black basal layer usually present, absent only in the thinner thalline parts. Perithecia completely immersed or in projecting warts; apex visible as black ring; ostiolar region concave. Exciple 150-230 $\mu \mathrm{m}$ diam., colourless to pale brown. Involucrellum reaching down to the thallus base and fusing in to the black basal layer. Ascospores (14.0-)15.8-17.5-19.2(-20.0) × (6.0-)6.1-6.8-7.6(-9.0) $\mu \mathrm{m}$, $1 / \mathrm{w}$ ratio $(2.0-) 2.2-2.6-2.9(-3.2), \mathrm{n}=25$, simple, narrowly ellipsoid, without perispore. Conidia 3-4.5 × $1.5 \mu \mathrm{m}$, oblong-ellipsoid.

Specimens examined: BULGARIA, Pirin Mts, the watershed of Demyanitsa River, cold stream above Valyavitsa River, sun exposed place in alpine environment, immersed in the water, substratum siliceous, $41.71244^{\circ} \mathrm{N}, 23.47013^{\circ} \mathrm{E}$, alt. $2197 \mathrm{~m}, 22 \mathrm{Jul}$ 2016, V.V. Shivarov (SOMF 29 516, 29 517).

Ecology and distribution. In Bulgaria, the species was found completely submerged in cold water, growing with Thelidium pertusatii and Verrucaria elaeomelaena agg. (Fig. 1). It is known from Europe (Austria, France, Germany, Great Britain, Iceland, Montenegro, Poland, Slovakia, and Switzerland) and North America (USA: Montana, Alaska), where it was observed on permanently or frequently submerged siliceous rocks, associated with 
Hydropunctaria rheitrophila, Verrucaria aquatilis, and V. funckii (Orange 2004; Thüs \& Schultz 2008, Bilovitz et al. 2009; Krzewicka 2012; McCune et al. 2014; Berger \& Türk 2015).

Comments. Hydropunctaria rheitrophila has a similar morphology, but differs in having pale green to brownish green colour of the thallus, absence of a black basal layer, by having an involucrellum developed in the upper half of exciple and smaller ascospores (9-14 × 6-9 $\mu \mathrm{m})$. Other freshwater lichens in the Verrucariaceae lack the combination of black punctae, dark basal layer and small ascospores.
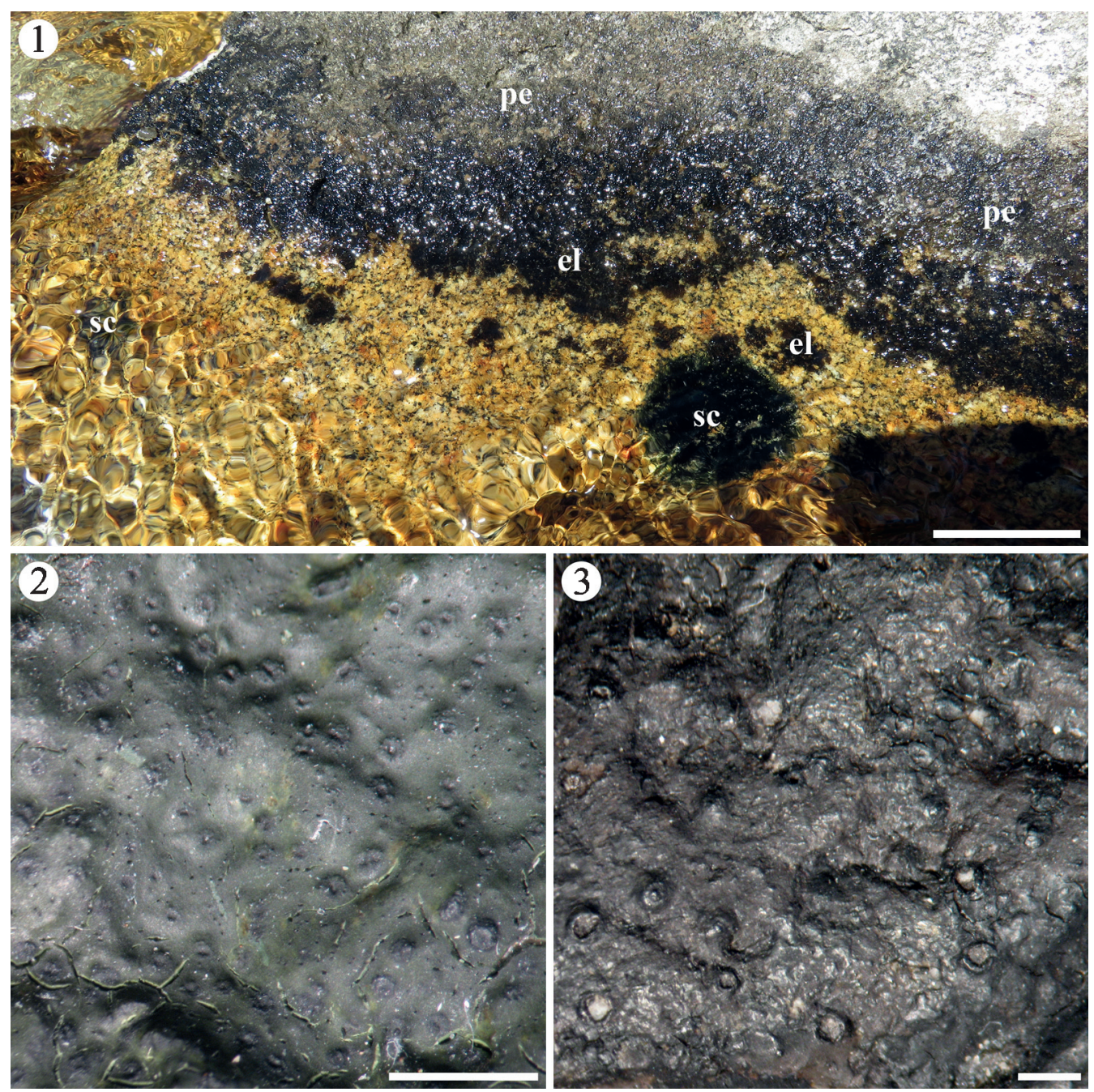

Fig. 1. Thalli forming lines in cold water stream: sc - Hydropunctaria scabra, pe - Thelidium pertusatii, el - Verrucaria elaeomelaena agg. Scale bar $=5 \mathrm{~cm}$. Fig. 2 . Hydropunctaria scabra (SOMF 29 516). Scale bar $=1 \mathrm{~mm}$. Fig. 3. Verrucaria alpicola (SOMF 29 488) Scale bar $=1 \mathrm{~mm}$ 
Verrucaria alpicola Zschacke, Hedwigia 67: 75, 1927.

Fig. 3

Thallus thin (up to $50 \mu \mathrm{m}$ thick), epilithic, subgelatinous, dark brown to almost black, continuous or slightly cracked around the perithecia, and in thicker parts of the thallus. Prothallus absent. Cortex paraplectenchymatous, with yellowish brown pigment, usually with disperse black patches; upper cortex dark brown to black. Black basal layer partly present. Perithecia covered by a thin thalline mantle, forming mounds $450-800 \mu \mathrm{m}$ diam.; apex exposed and visible as small black dot or immersed. Exciple 240-340 $\mu \mathrm{m}$ diam., entirely brown. Involucrellum reaching the exciple base and laterally spreading. Ascospores $(23.0-) 27.2-30.1-32.9(-35.5) \times(9.0-) 10.9-12.8-14.7(-18.0) \mu \mathrm{m}, 1 / \mathrm{w}$ ratio $(1.8-) 2.0-$ 2.3-2.7(-3.2), $\mathrm{n}=50$, ellipsoid to narrowly ellipsoid, without perispore. Conidiomata not observed.

Specimens examined: BULGARIA, Rila Mts, Malyovitsa River, the Second Ledge, on pebble submersed in the water, substratum siliceous, $42.177725^{\circ} \mathrm{N}, 23.373627^{\circ} \mathrm{E}$, alt. 2230 m, 31 Aug 2014, V.V. Shivarov (SOMF 29 488) (sub Verrucaria margacea group); 31 May 2015, V.V. Shivarov (SOMF 29 519).

Ecology and distribution. In Bulgaria, Verrucaria alpicola was found in a submersed place, growing together with Hydropunctaria rheitrophila in an alpine environment. The period of inundation is confirmed for four years. Observations were made from 2013 to 2016, during the periods of lowest water level. It is known from Europe (Austria, Great Britain, Germany, Italy, Norway, Romania, and Switzerland) where it is reported from the splash water zone and temporarily inundated sites in springs and headwaters. It was found growing on siliceous and calcareous substrata, mostly at high elevations in Central Europe (Zschacke 1927; Thüs et al. 2015).

Comments. Swinscow (1968) reduced Verrucaria alpicola to a synonym of $V$. margacea, but a recent study of the $V$. elaeomelaena species complex shows that $V$. apicola is a monophyletic species, nested in the $V$. elaeomelaena agg. The genetic diversity in the group of $V$. alpicola is high and more species can be expected when more sequences become available (Thüs et al. 2015). Verrucaria alpicola differs from other species in the $V$. elaeomelaena complex by large ellipsoid to narrowly ellipsoid ascospores with a length/ width ratio usually above 2.2 , an upper cortex with a dark brown to black pigment and an exciple which is brown down to the base.

Verrucaria margacea is a different species characterized by a non subgelatinous thallus (a thallus with air filled space surrounding the hyphae) and slender ascospores (Thüs et al. 2015).

Acknowledgements. The first author would like to thank Drs Nickolay Apostolov, Georgi Iliev, and Teodor T. Denchev for their assistance during the fieldwork. This work was supported by "Program for career development of young scientists, BAS". 


\section{References}

Berger, F. \& Türk, R. 2015. The amphibious lichen flora of the alpine headwater community "Lackenböden" in Dösental (Mallnitz, Carinthia, Austria). - Herzogia 28: 348-358. https://doi.org/10.13158/ heia.28.2.2015.348

Bilovitz, P.O., Knežević, B., Stešević, D. \& Mayrhofer, H. 2009. Lichenized and lichenicolous fungi from Bjelasica (Montenegro), with special emphasis on Biogradska Gora National Park. - Bibliotheca Lichenologica 99: 67-80.

Krzewicka, B. 2012. A revision of Verrucaria s.l. (Verrucariaceae) in Poland. - Polish Botanical Studies 27: 3-143.

McCune, B., Rosentreter, R., Spribille, T., Breuss, O. \& Wheeler. T. 2014. Montana lichens: an annotated list. - Monographs in North American Lichenology 2: 1-183.

Orange, A. 2004. A remarkable new freshwater Verrucaria from Europe. - Lichenologist 36: 349-354. https://doi.org/10.1017/S002428290401446X

Shivarov, V.V. 2013. New records of Verrucariaceae (Ascomycota) from Bulgaria. - Mycobiota 3: 11-17. https://doi.org/10.12664/mycobiota.2013.03.02

Shivarov, V.V. 2015. Taxonomic study of Verrucariaceae (lichenized fungi) in Bulgaria. PhD thesis. Institute of Biodiversity and Ecosystem Research, Bulgarian Academy of Sciences, Sofia. 196 pp. (In Bulgarian)

Smith, C.W., Aptroot, A., Coppins, B.J., Fletcher, A., Gilbert, O.L., James, P.W. \& Wolseley, P.A. (eds) 2009. The lichens of Great Britain and Ireland. $2^{\text {nd }}$ edn. The British Lichen Society, London.

Swinscow, T.D.V. 1968. Pyrenocarpous lichens: 13. Freshwater species of Verrucaria in the British Isles. Lichenologist 4: 34-54. https://doi.org/10.1017/S002428296800006X

Thüs, H. \& Schultz, M. 2008('2009'). Freshwater flora of Central Europe. Vol. 21/1, Fungi, Part 1, Lichens. Spektrum, Heidelberg.

Thüs, H., Aptroot, A. \& Seaward, M.R.D. 2014. Freshwater lichens. - In: E.B.G Jones, K.D. Hyde \& K.L. Pang (eds). Freshwater fungi and fungus-like organisms. Pp. 333-358. De Gruyter, Berlin.

Thüs, H., Orange, A., Gueidan, C., Pykälä, J., Ruberti, C., Lo Schiavo, F. \& Nascimbene, J. 2015. Revision of the Verrucaria elaeomelaena species complex and morphologically similar freshwater lichens (Verrucariaceae, Ascomycota). - Phytotaxa 197: 161-185. https://doi.org/10.11646/phytotaxa.197.3.1

Zschacke, H. 1927. Die mitteleuropäischen Verrucariaceen. V. - Hedwigia 67: 45-85. 